Journal of Epidemiology and Public Health (2019), 4(4): 270-282

https://doi.org/10.26911/jepublichealth.2019.04.04.02

\title{
Biological and Social Economic Determinants of Adherence and Cure of Tuberculosis Treatment: Path Analysis Evidence from Yogyakarta
}

\author{
Tri Godha Fitriani'), Setyo Sri Rahardjo²), Hanung Prasetya3) \\ 1)Masters Program in Public Health, Universitas Sebelas Maret, Surakarta \\ ${ }^{2)}$ Faculty of Medicine, Universitas Sebelas Maret \\ ${ }^{3)}$ School of Health Polytechnics Surakarta
}

\begin{abstract}
Background: Tuberculosis (TB) was an infectious disease which was still a health problem worldwide, including in Indonesia, which only had a population of around 261 million. The purpose of this study was to analyze biological and social economic determinants of adherence and cure of TB treatment.

Subjects and Method: This was an analytic observational study with a case control design. The study was conducted in Bantul, Yogyakarta, from April to May 2019. A sample of 225 TB patients was selected by random sampling. The dependent variable was adherence and cure of TB treatment. The independent variables were age, gender, education, family income, nutritional status, healthy behavior, complication, family support, drug taking supervisor, drug taking adherence, environment, and smoking. The data were collected by questionnaire and analyzed by path analysis.

Results: Adherence and cure of TB treatment was directly increased with good nutritional status $(b=076 ; 95 \% \mathrm{CI}=0.03$ to $1.49 ; \mathrm{p}=0.042)$, drug taking adherence $(\mathrm{b}=3.67 ; 95 \% \mathrm{CI}=1.47$ to 5.92 ; $\mathrm{p}=0.001)$, drug taking supervisor $(\mathrm{b}=3.64 ; 95 \% \mathrm{CI}=1.26$ to $6.02 ; \mathrm{p}=0.003)$, strong family support $(\mathrm{b}=2.03 ; 95 \% \mathrm{CI}=-3.85$ to $-0.21 ; \mathrm{p}=0.029)$, and healthy physical environment $(\mathrm{b}=4.05 ; 95 \% \mathrm{CI}=$ - 0.09 to 8.20; $\mathrm{p}=0.056$ ). Adherence and cure of TB treatment was directly decreased with age $\geq 65$ years old $(b=-0.54 ; 95 \% C I=-1.85$ to $0.75 ; p=0.411)$, female gender $(b=-0.05 ; 95 \% C I=-0.86$ to $0.76 ; \mathrm{p}=0.900)$, unhealthy behavior $(\mathrm{b}=-3.20 ; 95 \% \mathrm{CI}=-5.02$ to $-1.36 ; \mathrm{p}=0.001)$, smoking $(\mathrm{b}=-$ 1.50; 95\% $\mathrm{CI}=-2.56$ to $-0.43 ; \mathrm{p}=0.006)$, complication $(\mathrm{b}=-1.41 ; 95 \% \mathrm{CI}=-2.60$ to $-0.23 ; \mathrm{p}=$ 0.019). It was indirectly affected by nutritional status, education, family income, and healthy environment.

Conclusions: Adherence and cure of TB treatment is directly increased with good nutritional status, drug taking adherence, drug taking supervisor, strong family support, and healthy physical environment. Adherence and cure of TB treatment is directly decreased with age $\geq 65$ years old, female gender, unhealthy behavior, smoking, complication. It is indirectly affected by nutritional status, education, family income, and healthy environment.
\end{abstract}

Keywords: tuberculosis treatment, drug taking adherence, path analysis

\section{Correspondence:}

Tri Godha Fitriani. Masters Program in Public Health, Universitas Sebelas Maret. Jl. Ir. Sutami 36A, Surakarta 57126, Central Java. Email: trigodha@gmail.com. Mobile: +6287738200610.

\section{BACKGROUND}

Tuberculosis (TB) is still a health problem throughout the world, including Indonesia which has a population of around 261 million, Indonesia is ranked 2nd in the world in the number of TB cases, both in the number of cases and new cases. According to the World Health Organization, in 2017, there were an estimated 1,020,000 TB cases in Indonesia, but only 420,000 cases have been reported to the Ministry of Health. The number beats China in third place which has around 1.4 
billion people. Only one country has a worse number of TB cases from Indonesia, namely India which has a population of 1.3 billion (Ministry of Health, 2018).

In 2009, mortality and morbidity caused by Mycobacterium tuberculosis germs were 1.7 million people $(600,000$ of them women) and 9.4 million new cases of TB (3.3 million of them women). One third of the world population has contracted TB where most TB sufferers are of productive age (15-55 years) (Ministry of Health, 2018).

TB treatment recovery is expected to be at a minimum percentage of $85 \%$ to reduce the burden of $\mathrm{TB}$ incidence and recurrence. To reach $85 \%$ cure rate, at least $85 \%$ - $90 \%$ patient compliance is needed. This disobedience to treatment will increase the burden of failure to treat treatment and the greatest risk of the program is Multi Drug Resistance (MDR) TB (WHO, 2017).

Pulmonary TB cases in 2017 in Bantul Regency increased from the one 2016 by $39.64 \%$, which was previously $34.89 \%$. The number of deaths from TB is reported to be 3 people. The success rate consists of recovery rates and the complete treatment of pulmonary TB. The success rate in 2017 is reported to be at $65 \%$. Cure rate in 2017 was reported at $76.38 \%$. The cure rate for TB treatment in Bantul Regency in 2017 rose when compared with 2016 of $71 \%$ and this cure rate was also below the National target (85\%). District with the highest number of cases in Banguntapan I health center as many as 31 people (Bantul Health Profile, 2018)

DOTS strategy is an effective strategy to stop the spread of TB. Therefore, WHO recommends this strategy with five components, namely, political commitment, microscopic determination of diagnosis, drug swallow supervision (PMO), availability of anti-TB medicine that is sustainable, and good and correct recording and reporting systems (Nizar, 2017). In addition to DOTS, the government also has a TB Partnership forum, which is a partnership group consisting of various organizations and individuals jointly agreeing to help overcome the TB problem. The indicator of the success of the forum is the contribution of the forum in supporting the Government to achieve the national TB control target, mobilizing resources, especially in terms of funding, policies issued in supporting TB control efforts.

The success of the TB control program focuses on program management and the availability of resources as an effort to achieve effective and efficient goals (Ministry of Health, 2018). Puskesmas (community health center) was primary health care providers that were required to provide services towards universal access to quality TB services by increasing the coverage and quality of DOTS services. Efforts to achieve the objectives of the TB program needed to get support through the implementation of the system, both from policy makers including the head of the health center and the officers in the TB program, so that it was expected to reach the other target indicators that had been set.

This study aims to analyze the determinants of cure for tuberculosis sufferers.

\section{SUBJECTS AND METHOD}

\section{a. Study Design}

This was an analytic observational study with a case control design. This study was conducted in 6 community health centers in Bantul, Yogyakarta, from April to May 2019.

\section{b. Population and Samples}

The target population in this study was tuberculosis patients in Pundong, Bam- 
Journal of Epidemiology and Public Health (2019), 4(4): 270-282

https://doi.org/10.26911/jepublichealth.2019.04.04.02

banglipuro, Sewon II, Banguntapan II, Pleret, and Piyungan community health centers, Bantul, Yogyakarta. A sample of $225 \mathrm{~TB}$ patients was selected by random sampling.

\section{c. Study Variables}

The dependent variable in this study was healing TB patients. The independent variables in this study were age, gender, education level, economic status, nutritional status, behavior, compliance, PMO, family support, smoking, complications with other diseases, and physical environment.

\section{d. Operational Definition of Variables} Adherence and cure of TB treatment. The cure for TB was declared as cured if it had completed the complete treatment, with repeated examination of phlegm at least two consecutive negative times in the month before the end of treatment or the end of the intensive phase and previous follow-up examination. The data were obtained from medical record.

Age. Age of TB patients was length of time from birth to being cured of TB illness. The data were collected by questionnaire.

Gender. Gender was an individual differrence based on sex. The data were collected by questionnaire. The measurement scale was categorical.

Education. The level of education refers to formal education that has been taken by the subjects, based on the last diploma owned starting from a level of elementary, junior high, high school, and college. The data were collected by questionnaire. The measurement scale was categorical.

Family Income. Family income was the amount of income received by the nuclear family (husband, wife, children who have worked) produced every month, which is expressed in rupiah. The data were collected by questionnaire. The measurement scale was continous.
Nutritional Status. Nutritional status was defined as the nutritional status of TB patients while undergoing TB treatment. The data were collected by questionnaire.

Complication. Complication was defined as TB patients who had other diseases. The data were obtained from medical record.

Drug taking supervisor. Drug taking supervisor was family member who was close to the subject or health workers who always reminds the schedule of taking medication, sees and helps swallow medicine, and helps the subject in consulting his illness and taking drugs to health care facilities. The data were collected by questionnaire.

Physical Environment. Physical environment is a condition of the physical environment of a healthy home seen from the layout, the state of the ceiling, walls, floors, room windows, ventilation, kitchen smoke holes, lighting and residential solids. The data were collected by questionnaire.

Drug taking adherence. Drug taking adherence was defined as the obedience and accuracy of $\mathrm{TB}$ patients in taking drugs according to the time and amount prescribed by doctor. The data were collected by questionnaire.

Family Support. Family support was all forms of support provided by the family to improve compliance with medical treatment for the subject. The data were collected by questionnaire.

Attitude. Attitude was an action carried out by patients in TB treatment. The data were collected by questionnaire.

Smoking. Smoking was defined as smoking habit carried out by TB patients. The data were collected by questionnaire.

\section{e. Data Analysis}

Univariate analysis described the characteristics of variables based on the results of the study. Bivariate analysis in the study was conducted to determine the relation- 
ships between independent and the dependent variable was done using the chi-square test. Multivariate analysis was conducted using path analysis to determine the magnitude of the influence directly or indirectly on variables.

\section{f. Research Ethics}

Research ethics in this study included informed consent, anonymity, confidentiality, and research ethics. Research ethics was obtained from Research Ethics Committee at Dr. Moewardi Hospital, Surakarta, with the number: 499 / IV / HREC / 2019.

\section{$\frac{\text { RESULTS }}{\text { 1. Univariate Analysis }}$}

Tables 1 and 2 showed the characteristics of respondents and other variables, using continuous data and categorical data. Tables 1 and 2 showed sample characteristics and other variables, using continous and categorical data.

\section{Bivariate Analysis}

Table 3 showed the results of bivariate analysis. Table 3 showed that nutritional status was associated with cure of TB treatment. TB patients with good nutritional status increased cure of $\mathrm{TB}$ treatment $(\mathrm{OR}=$ 2.13; $\mathrm{p}=0.042$ ).

Complication was associated with cure of TB treatment. Complication decreased cure of TB treatment $(\mathrm{OR}=0.24 ; \mathrm{p}=0.019)$.

Drug taking supervisor was associated with cure of TB treatment. Drug taking supervisor increased cure of TB treatment $(\mathrm{OR}=38.12 ; \mathrm{p}=0.003)$.

Physical environment was associated with cure of TB treatment. Good physical environment increased cure of TB treatment $(\mathrm{OR}=57.56 ; \mathrm{p}=0.056)$.

Drug taking adherence was associated with cure of TB treatment. Drug taking adherence decreased cure of TB treatment $(\mathrm{OR}=0.42 ; \mathrm{p}=0.001)$.

Family support was associated with cure of TB treatment. Strong family support decreased cure of $\mathrm{TB}$ treatment $(\mathrm{OR}=0.13$; $\mathrm{p}=0.029$ ).

Attitude was associated with cure of TB treatment. Negative attitude decreased cure of TB treatment (OR=0.04; $\mathrm{p}=0.001)$.

Smoking was associated with cure of TB treatment. Smoking decreased cure of $\mathrm{TB}$ treatment $(\mathrm{OR}=0.22 ; \mathrm{p}=0.006)$.

Table 1. Sample characteristics (continuous data)

\begin{tabular}{llcccc}
\hline \multicolumn{1}{c}{ Variable } & (n) & Mean & SD & Min. & Max. \\
\hline Age (year) & 225 & 44 & 16 & 16 & 75 \\
Income (Rupiah) & 225 & $1,569,333$ & 430,004 & 1,000, ooo & 3, ooo,ooo \\
Nutritional Status (BMI) & 225 & 11.39 & 933.61 & 14.03 & 28.34 \\
Environment & 225 & 11.39 & 0.89 & 9 & 14 \\
Drug taking adherence & 225 & 7.39 & 0.83 & 5 & 9 \\
Family Support & 225 & 7.09 & 1.14 & 4 & 9 \\
Attitude & 225 & 4.14 & 0.53 & 3 & 5 \\
\hline
\end{tabular}

\section{Path Analysis}

\section{a. Model Specification}

Model specifications described the relationship between the variables studied. In this study, there were measured variables, namely age, gender, education level, family income, nutritional status, behavior, complications, family support, PMO, adhe- rence to medication, environment, and smoking.

\section{b. Model Identification}

Measured variable were:

1) Measured variable $\quad=13$

2) Endogenous variable $\quad=5$

3) Exogenous variable $=8$

4) Total parameter $\quad=13$ 
Journal of Epidemiology and Public Health (2019), 4(4): 270-282

https://doi.org/10.26911/jepublichealth.2019.04.04.02

Degree of freedom $(\mathrm{df})=$ (number of measured variables $\mathrm{x}$ (number of measured variables +1$) / 2)$ - (endogenous variable + exogenous variable + number of parameters $)=(13 \times(13+1) / 2)-(5+8+13)$ $=91-26=65$

The result of the degree of freedom (df) was 65 which mean that over identified or path analysis can be done. Table 4 showed the results of path analysis.

Table 4 showed that there was a direct and negative association between age and cure of TB treatment, but it was statistically non-significant. Age $\geq 65$ years decreased logodd cure of treatment 0.54 units $(b=-0.54 ; 95 \% \mathrm{CI}=-1.85$ to $0.75 ; \mathrm{p}=$ $0.411)$.

There was a direct and negative association between gender and cure of treatment, but it was statistically nonsignificant. Male patients decreased logodd cure of treatment 0.05 units $(b=-0.05$; $95 \% \mathrm{CI}=-0.86$ to $0.76 ; \mathrm{p}=0.900$ ).

Table 2. Sample Characteristics (categorical data)

\begin{tabular}{|c|c|c|}
\hline Characteristics & Frequency (n) & Percentage (\%) \\
\hline \multicolumn{3}{|l|}{ Age } \\
\hline $15-64$ years & 199 & 88.44 \\
\hline$\geq 65$ years & 26 & 11.56 \\
\hline \multicolumn{3}{|l|}{ Gender } \\
\hline Male & 125 & $55 \cdot 56$ \\
\hline Female & 100 & 44.44 \\
\hline \multicolumn{3}{|l|}{ Education } \\
\hline$<$ Senior high school & 99 & 44.20 \\
\hline$\geq$ Senior high school & 125 & 55.80 \\
\hline \multicolumn{3}{|l|}{ Family Income } \\
\hline$<\operatorname{Rp} 1,527,150$ & 125 & 55.56 \\
\hline$\geq \operatorname{Rp} 1,527,150$ & 100 & 44.44 \\
\hline \multicolumn{3}{|l|}{ Nutritional Status } \\
\hline $\mathrm{BMI}<18.5$ or $>25$ & 148 & $65 \cdot 78$ \\
\hline BMI 18.5 to 25 & 77 & 34.22 \\
\hline \multicolumn{3}{|l|}{ Complication } \\
\hline No & 183 & 81.33 \\
\hline Yes & 42 & 18.67 \\
\hline \multicolumn{3}{|c|}{ Drug taking supervisor } \\
\hline No & 33 & 14.67 \\
\hline Yes & 192 & $85 \cdot 33$ \\
\hline \multicolumn{3}{|l|}{ Environment } \\
\hline Unhealthy & 30 & 13.33 \\
\hline Healthy & 195 & 86.67 \\
\hline \multicolumn{3}{|c|}{ Drug taking adherence } \\
\hline No & 44 & 19.56 \\
\hline Yes & 181 & 80.44 \\
\hline \multicolumn{3}{|l|}{ Family Support } \\
\hline Weak & 25 & 11.11 \\
\hline Strong & 200 & 88.89 \\
\hline \multicolumn{3}{|l|}{ Attitude } \\
\hline Poor & 24 & 10.67 \\
\hline Good & 201 & 89.33 \\
\hline \multicolumn{3}{|l|}{ Smoking } \\
\hline No & 162 & 72.00 \\
\hline Yes & 63 & 28.00 \\
\hline
\end{tabular}


Table 3. The results of bivariate analysis

\begin{tabular}{|c|c|c|c|c|c|c|c|c|}
\hline \multirow{3}{*}{$\begin{array}{c}\text { Independent } \\
\text { variables }\end{array}$} & \multicolumn{4}{|c|}{ Cure of TB treatment } & \multirow{2}{*}{\multicolumn{2}{|c|}{ Total }} & \multirow{3}{*}{$\mathbf{O R}$} & \multirow{3}{*}{$\mathbf{p}$} \\
\hline & \multicolumn{2}{|c|}{ Yes } & \multicolumn{2}{|c|}{ No } & & & & \\
\hline & $\mathbf{N}$ & $\%$ & $\mathbf{n}$ & $\%$ & $\mathbf{N}$ & $\%$ & & \\
\hline \multicolumn{9}{|l|}{ Age } \\
\hline $15-64$ years & 70 & 93.33 & 129 & 86.00 & 199 & 88.44 & \multirow{3}{*}{0.58} & \multirow{3}{*}{0.313} \\
\hline$\geq 65$ years & 5 & 6.67 & 21 & 14.00 & 26 & 11.56 & & \\
\hline \multicolumn{7}{|l|}{ Education } & & \\
\hline$<$ SHS & 34 & $45 \cdot 33$ & 66 & 44 & 100 & 44.44 & \multirow{3}{*}{0.41} & \multirow{3}{*}{0.099} \\
\hline$\geq$ SHS & 41 & 54.67 & 84 & 56 & 125 & $55 \cdot 56$ & & \\
\hline \multicolumn{7}{|l|}{ Family Income } & & \\
\hline$<\operatorname{Rp} 1,527,150$ & 34 & $45 \cdot 33$ & 94 & 62.67 & 128 & 56.89 & \multirow{3}{*}{1.88} & \multirow{3}{*}{0.244} \\
\hline$\geq \operatorname{Rp} 1,527,150$ & 41 & 54.67 & 56 & $37 \cdot 33$ & 97 & 43.11 & & \\
\hline \multicolumn{7}{|l|}{ Nutritional Status } & & \\
\hline IMT $<18.5$ or $>25$ & 34 & $45 \cdot 33$ & 114 & 76.00 & 148 & 65.78 & \multirow{3}{*}{2.13} & \multirow{3}{*}{0.042} \\
\hline IMT 18.5 to 25 & 41 & 54.67 & 36 & 24.00 & 77 & 34.22 & & \\
\hline \multicolumn{7}{|l|}{ Complication } & & \\
\hline No & 71 & 94.67 & 112 & 74.67 & 183 & 81.33 & \multirow{3}{*}{0.24} & \multirow{3}{*}{0.019} \\
\hline Yes & 4 & 5.33 & 38 & $25 \cdot 33$ & 42 & 18.67 & & \\
\hline \multicolumn{7}{|l|}{ PMO } & & \\
\hline Do not have & 2 & 2.67 & 32 & 21.33 & 34 & 15.11 & \multirow{3}{*}{38.12} & \multirow{2}{*}{0.003} \\
\hline Have & 73 & 94.33 & 118 & 78.67 & 191 & 84.89 & & \\
\hline \multicolumn{8}{|l|}{ Environment } & \\
\hline Unhealthy & 1 & 1.33 & 29 & 19.33 & 30 & 13.33 & \multirow{3}{*}{$57 \cdot 56$} & 0056 \\
\hline Healthy & 74 & 98.67 & 121 & 80.67 & 195 & 86.67 & & 0.050 \\
\hline Compliance & & & & & & & & \\
\hline No & 2 & 2.67 & 42 & 28 & 44 & 19.65 & & \\
\hline Yes & 73 & $97 \cdot 33$ & 108 & 72 & 181 & 80.44 & 40.42 & 0.001 \\
\hline Family Support & & & & & & & & \\
\hline Weak & 8 & 10.67 & 17 & 11.33 & 25 & 11.11 & 0.13 & 0.029 \\
\hline Strong & 67 & 89.33 & 133 & 88.67 & 200 & 88.89 & 0.13 & 0.029 \\
\hline Attitude & & & & & & & & \\
\hline Lacking & 14 & 18.67 & 10 & 6.67 & 24 & 10.67 & 04 & 0001 \\
\hline Good & 61 & 81.33 & 140 & $93 \cdot 33$ & 201 & 89.33 & 0.04 & 0.001 \\
\hline Smoking & & & & & & & & \\
\hline No & 61 & 81.33 & 100 & 66.67 & 161 & 71.56 & 0.22 & 0.006 \\
\hline Yes & 14 & 18.67 & 50 & 33.33 & 64 & 28.44 & 0.22 & \\
\hline
\end{tabular}

There was a direct and positive association between nutritional status and cure of treatment and it was statistically significant. Good nutritional status increased logodd of cure treatment 0.76 units ( $b=076 ; 95 \% \mathrm{CI}=0.03$ to $1.49 ; \mathrm{p}=0.042$ ).

There was a direct and negative association between attitude and cure of treatment and it was statistically significant. Negative attitude decreased logodd cure of treatment 3.20 units $(b=-3.20 ; 95 \% \mathrm{CI}=$ 5.02 to $-1.36 ; \mathrm{p}=0.001$ ).

There was a direct and positive association between drug taking adherence and cure of treatment and it was statistically significant. Adherent drug taking increased logodd of cure treatment 3.67 units $(b=$ $3.67 ; 95 \% \mathrm{CI}=1.47$ to $5.92 ; \mathrm{p}=0.001$ ).

There was a direct and positive association between drug taking supervisor and cure of treatment and it was statistically significant. Drug taking supervisor increased logodd cure of treatment 3.64 units $(b=3.64 ; 95 \% \mathrm{CI}=1.26$ to $6.02 ; \mathrm{p}=$ o.003).

There was a direct and negative association between family support and cure of treatment and it was statistically significant. 
Strong family support increased logodd cure of treatment 2.03 units $(b=2.03 ; 95 \%$ $\mathrm{CI}=-3.85$ to $-0.21 ; \mathrm{p}=0.029$ ).

There was a direct and negative influence of smoking habit and the cure of tuberculosis patients which was statistically significant. Tuberculosis patients who smoke have a logodd for recovery by 1.50 units lower than those who did not smoke ( $b=-1.50$; CI 95\%=-2.56 to $-0.43 ; \mathrm{p}=0.006$ ).

There was a direct and negative influence of patients who have other complications of the disease on the cure of tuberculosis patients and the effect was statistically significant. Tuberculosis patients who have other disease complications have a logodd for recovery by 1.41 units lower than patients who did not have complications from other diseases $(b=-1.41 ; C I$ $95 \%=-2.60$ to $-0.23 ; \mathrm{p}=0.019$ ).

There was a direct and positive influence between a healthy physical environment and the recovery of tuberculosis patients and the effect was statistically nearly significant. Tuberculosis patients with a healthy physical environment had a logodd for recovery by 4.05 units higher than patients with an unhealthy physical environment $(b=4.05$; CI $95 \%=-0.09$ to 8.20; $\mathrm{p}=0.056$ ).

Behavior was indirectly and positively related to the recovery of tuberculosis patients through adherence and it was statistically significant. Tuberculosis patients with good behavior had logodd to get adherence by 1.07 units higher than patients with poor behavior ( $\mathrm{b}=1.07$; CI $95 \%=0.14$ to $1.99 ; \mathrm{p}=0.024)$.

PMO was indirectly and positively related to the recovery of tuberculosis patients through adherence and it was statistically significant. Tuberculosis patients who have PMO have logodd to get compliance by 1.17 units higher than patients who did not have PMO ( $b=1.17$; CI $95 \%=0.37$ to 1.98; $\mathrm{p}=0.004$ ).

Family support was indirectly and positively related to the recovery of tuberculosis patients through nutritional status and it was statistically significant. Tuberculosis patients who have strong family support have logodd to get nutritional status by 1.17 units higher than patients who got lack of family support $(b=1.17$; CI $95 \%=0.04$ to $2.31 ; \mathrm{p}=0.043$ ).

Family income was indirectly and positively related to the recovery of tuberculosis patients through nutritional status and it was statistically significant. Tuberculosis patients with economic status of $\geq$ Rp 1,527,150 have logodd to get nutritional status by 1.22 units higher than patients with low family income $(b=1.22$; CI $95 \%=0.64$ to $1.80 ; \mathrm{p}<0.001$ ).

The level of education was indirectly and positively related to the recovery of tuberculosis patients through economic status and it was statistically significant. Tuberculosis patients with education level $\geq$ HS have logodd to get family income by 2.80 units higher than patients who were $<\mathrm{HS} \quad(\mathrm{b}=2.80$; $\mathrm{CI} \quad 95 \%=2.09$ to 3.52 ; $\mathrm{p}<0.001)$.

Family income was indirectly and positively related to the recovery of tuberculosis patients through the physical environment and it was statistically significant. Tuberculosis patients with family income $\geq$ Rp. 1.527.150 have logodd to obtain a healthy environment by 1.09 units higher than patients with low income $(b=1.09$; CI $95 \%=0.20$ to $1.98 ; \mathrm{p}=0.016$ ). 


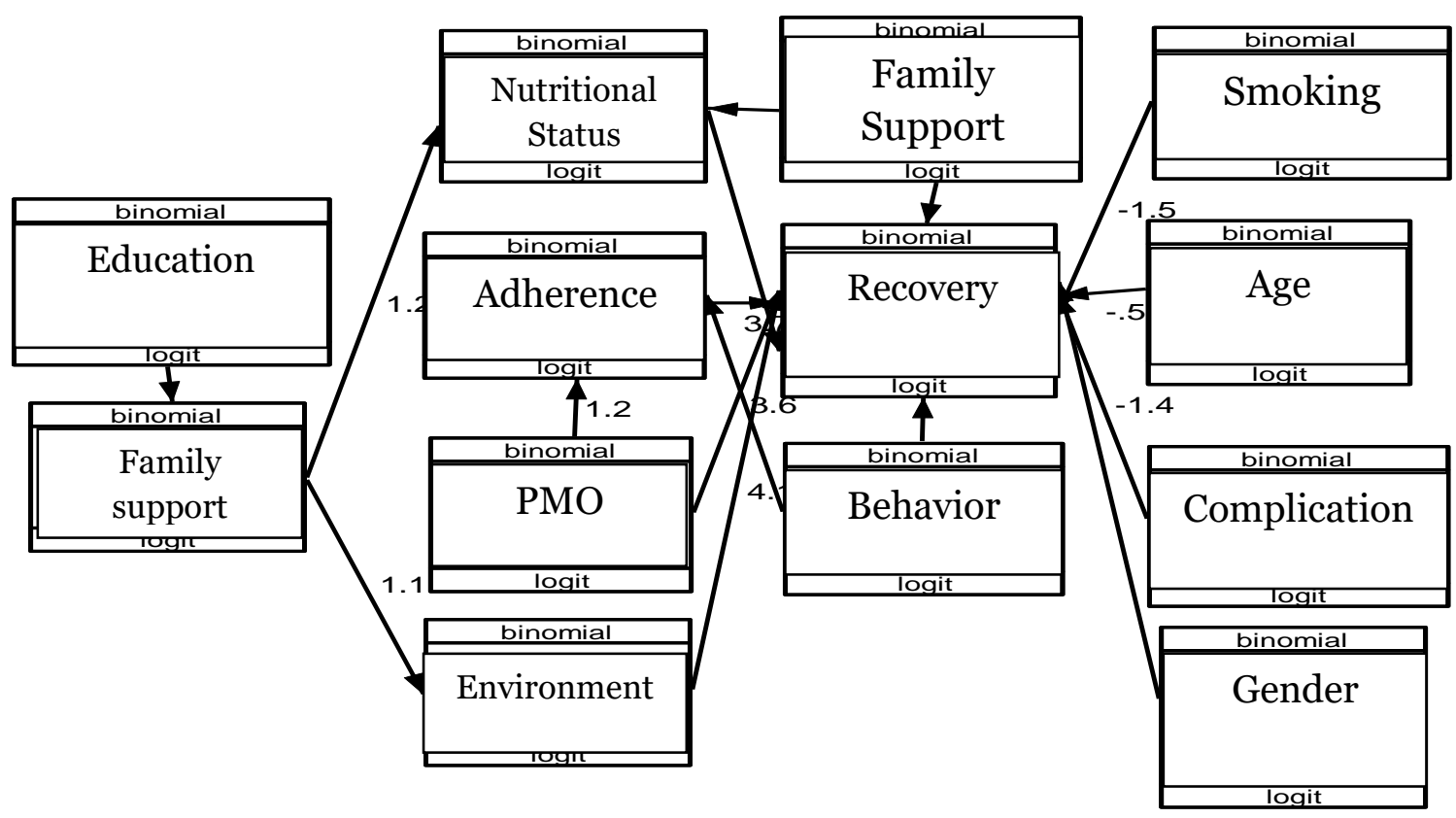

Figure 1. Structural Model of Path Analysis

Table 4. The results of path analysis of TB patients' recovery

\begin{tabular}{|c|c|c|c|c|c|}
\hline \multirow[b]{2}{*}{ Dependent Variables } & \multirow{2}{*}{ Independent Variables } & \multirow[b]{2}{*}{ (b) } & \multicolumn{2}{|c|}{ CI 95\% } & \multirow[b]{2}{*}{$\mathbf{p}$} \\
\hline & & & $\begin{array}{l}\text { Lower } \\
\text { Limit }\end{array}$ & $\begin{array}{l}\text { Upper } \\
\text { Limit }\end{array}$ & \\
\hline \multicolumn{6}{|l|}{ Direct Effect } \\
\hline \multirow[t]{10}{*}{ Cure of treatment } & $\leftarrow$ Age $(\geq 65$ years old $)$ & -0.54 & -1.85 & 0.75 & 0.411 \\
\hline & $\leftarrow$ Gender (Female) & -0.05 & -0.86 & 0.76 & 0.900 \\
\hline & $\leftarrow$ Nutritional Status (Good) & 0.76 & 0.03 & 1.49 & 0.042 \\
\hline & $\leftarrow$ Behavior (Good) & -3.20 & -5.02 & -1.36 & 0.001 \\
\hline & $\leftarrow$ Adherence (High) & 3.67 & 1.47 & 5.92 & 0.001 \\
\hline & $\leftarrow \mathrm{PMO}(\mathrm{Yes})$ & 3.64 & 1.26 & 6.02 & 0.003 \\
\hline & $\leftarrow$ Family Support (Good) & -2.03 & -3.85 & -0.21 & 0.029 \\
\hline & $\leftarrow$ Smoking (Yes) & -1.50 & -2.56 & -0.43 & 0.006 \\
\hline & $\leftarrow$ Complication (Yes) & -1.41 & -2.60 & -0.23 & 0.019 \\
\hline & $\leftarrow$ Environment (Healthy) & 4.05 & -0.09 & 8.20 & 0.056 \\
\hline \multicolumn{6}{|l|}{ Indirect Effect } \\
\hline \multirow[t]{2}{*}{ Drug taking adherence } & $\leftarrow$ Attitude (Positive) & 1.07 & 0.14 & 1.99 & 0.024 \\
\hline & $\leftarrow$ Drug taking supervisor & 1.17 & 0.37 & 1.98 & 0.004 \\
\hline \multirow[t]{2}{*}{ Nutritional Status } & $\leftarrow$ Family Support (Strong) & 1.17 & 0.04 & 2.31 & 0.043 \\
\hline & $\leftarrow$ Family Income (High) & 1.22 & 0.64 & 1.80 & $<0.001$ \\
\hline Family Income & $\leftarrow$ Educational (High) & 2.80 & 2.09 & 3.52 & $<0.001$ \\
\hline Environment & $\leftarrow$ Family Income (High) & 1.09 & 0.20 & 1.98 & 0.016 \\
\hline $\mathrm{N}$ observation $=\mathbf{2 2 5}$ & & & & & \\
\hline Log likelihood=530.07 & & & & & \\
\hline
\end{tabular}

\section{The Effect of Age on TB Patients Recovery}

The result of analysis showed that there was a direct and negative effect between age and the cure of tuberculosis patients and which was not statistically significant $(\mathrm{b}=-$ 0.54 ; CI $95 \%=-1.85$ to $0.75 ; \mathrm{p}=0.411$ ). Tuberculosis patients aged $\geq 65$ years old had a logodd for recovery by 0.54 units lower than patients aged 15-64 years old. 
This study was not in line with Jalal et al. (2017) who explain that patients who were one year older have a risk of recovery by 1 time than patients who were one year younger. Whereas Perez et al. (2012) state that age has no significant effect.

\section{The Effect of Gender on TB Patients Recovery}

The result of analysis showed that there was a direct and negative influence of gender and the cure of tuberculosis patients which was statistically insignificant $(\mathrm{b}=-$ 0.05; CI $95 \%=-0.86$ to $0.76 ; \mathrm{p}=0.900$ ). Male patients had logodd to recover by 0.05 units lower than female patients.

This study was not in line with Jalal et al. (2017) who explain that male can reduce the recovery of $\mathrm{TB}$ patients due to the possibility of becoming a drug addict.

Most tuberculosis occurred in men because there were several factors that may be carried out by patients, such as smoking or drinking alcohol. While Khaliq et al. (2015) explain that male was more likely of developing disease at $\mathrm{OR}=1.51$.

\section{The Effect of Educational Level on TB Patients Recovery}

The result of analysis showed that there was an indirect and positive influence between the level of education and the recovery of TB patients through economic status and it was statistically significant (b $=2.80 ; 95 \% \mathrm{CI}=2.09$ to $3.52 ; \mathrm{p}=<0.001)$. This study showed that a high level of education increased the recovery of $\mathrm{TB}$ patients through family income by 2.80 times higher than TB patients with low level of education.

Study conducted by Kholifah (2009) showed that the level of education had no relationship with the recovery of patients with pulmonary TB. Perez et al. (2012) explain that low education reduces the recovery of TB patients. This study was also supported by Ndwandwe et al. (2018) who state that high education can improve the recovery of TB patients.

A study done by Puspitasari et al. (2017) explain that there is an indirect effect of the level of education on the cure of pulmonary TB treatment in the City of Mojokerto. The results of the analysis show that the effect of the level of education on healing occurs indirectly through intermediate variables, namely nutritional status and treatment compliance. The level of education has a positive influence on nutritional status and it was statistically significant. The level of education also had a positive effect on treatment compliance and it was statistically nearly significant.

\section{The Effect of Family Income on TB Patients Recovery}

The result of analysis showed that there was an indirect and positive influence of family income on the recovery of tuberculosis patients through the physical environment and it was statistically significant $(\mathrm{b}=1.09 ; 95 \% \mathrm{CI}=0.20$ to $1.98 ; \mathrm{p}=0.016)$. This study showed that high economic status increased the cure of TB patients by 1.09 times higher compared to patients with low family income.

This was in accordance with the study conducted by Djibuti et al. (2014) which state that high family income can improve the recovery of TB patients. The similar idea was expressed by Puspitasari et al. (2017) who suggest that the effect of family income on healing treatment in pulmonary TB patients was indirectly through nutritional status and treatment compliance. Family income has a positive effect on nutritional status and treatment compliance and it was statistically significant. High family income can increase the likelihood of improving patient's nutritional status and be more obedient in carrying out the treatment. 


\section{The Effect of Nutritional Status on TB Patients Recovery}

The result of analysis showed that there was a direct and positive effect of nutritional status and recovery of TB patients and the effect was statistically significant $(b=$ $0.76 ; 95 \% \mathrm{CI}=0.03$ to $1.49 ; \mathrm{p}=0.042$ ). This study showed that patients with normal nutritional status can improve recovery by 0.76 times higher than those with abnormal nutritional status.

The results of this study were in accordance with theory of Supariasa which stated that poor nutritional conditions can facilitate infection (pulmonary TB). The more advanced prosperity of a country, the fewer people affected by pulmonary TB. With the decline of the immune system, all infectious diseases were easily attacked including pulmonary TB (Danusantoso, 2000) in (Kholifah, 2009).

\section{The Effect of Complication on TB Patients Recovery}

The result of analysis showed that the complications of other diseases can reduce the cure of TB patients by 1.41 times higher compared to patients who did not have complications.

Misnadiarly (2006) in Kholifah (2009) states that complications to other diseases were a factor for healing TB patients where sufferers who have complications can reduce the recovery of TB. Complications that were often experienced by sufferers such as DM, patients with long diabetes were cured because their body defenses were lower compared to Non-DM people, and it was easier for them to suffer from TB. This was in line with Goldhaber et al. (2011) who state that DM patients were less likely to recover than non-DM patients.

A study conducted by Ndwan-dwe et al. (2018) state that patients with coinfected HIV were 2 times more likely to stop TB treatment because it became more painful if the patient consumed OAT.

\section{The Effect of PMO on TB Patients Recovery}

The result of analysis showed that there was an indirect and positive influence of PMO and recovery of TB patients through adherence and it was statistically significant ( $\mathrm{b}=1.17$; 95\% CI $=0.37$ to $1.98 ; \mathrm{p}=0.004$ ). This study showed that TB patients who have PMO can increase the recovery by 1.17 times higher than patients who did not have PMO.

PMO was needed for TB sufferers to guarantee treatment settings starting from taking the medicine to the supervision of taking the medicine. But the main task of the PMO was not only to take drugs, the main task of PMO was supervision and must be active in providing important information needed by TB patients.

Hamidi et al. (2019) state that there was a direct effect of PMO on compliance of TB patients. The existence of PMO improved patients' compliance, and it can help them to recover from TB disease.

\section{The Effect of Environment on TB Patients Recovery}

The result of analysis showed that there was a direct and positive influence of a healthy physical environment and the recovery of TB patients and the effect was statistically nearly significant $(b=4.05 ; 95 \%$ $\mathrm{CI}=-0.09$ to 8.20; $\mathrm{p}=0.056)$. This study showed that patients with a healthy environment can improve the recovery by 4.05 times higher than those with an unhealthy physical environment.

Khaliq et al. (2015) mention that the environment is very important to control the spread of infection and disease. In line with Resino et al. (2016) who state that a healthy environment can improve the recovery of TB patients. 
Journal of Epidemiology and Public Health (2019), 4(4): 270-282

https://doi.org/10.26911/jepublichealth.2019.04.04.02

\section{The Effect of Adherence on TB Patients Recovery}

The result of analysis showed that there was a direct and positive influence of medication compliance on the cure of tuberculosis patients and the effect was statistically significant $(\mathrm{b}=3.67 ; 95 \% \mathrm{CI}=1.47$ to $5.92 ; \mathrm{p}=0.001)$. This study showed that TB patients with high adherence can increase cure by 3.67 times higher than those with less compliance.

This was in accordance with the theory of Danusantoso (2000) in Kholifah (2009) which state that adherence to taking medication is very important in healing TB patients. If the patient is not adhere in drinking OAT, there would be healing failure and the emergence of multiresisten TB bacilli.

\section{The Effect of Family Support on TB Patients Recovery}

The result of analysis showed that There was an indirect and positive effect of family support and the recovery of TB patients through nutritional status and it was statistically significant $(b=1.17 ; 95 \% \mathrm{CI}=$ 0.04 to $2.31 ; \mathrm{p}=0.043)$. This study showed that TB patients with good family support can improve recovery by 1.17 times higher compared to patients who have lack of family support.

This was in line with Puspitasari et al. (2017) who explain that strong family support can improve the recovery of $\mathrm{TB}$ patients. Whereas Hamidi et al. (2019) explain that strong family support can improve the compliance of TB patients.

\section{The Effect of Behavior on TB Patients Recovery}

The result of analysis showed that there was a direct and negative influence of behavior on the recovery of TB patients and the effect was statistically significant $(\mathrm{b}=$ 3.20; $95 \% \mathrm{CI}=-5.02$ to $-1.36 ; \mathrm{p}=0.001$ ). This study showed that TB patients with good behavior can reduce recovery by 3.20 times higher than patients with poor behavior.

A study by Kholifah (2009) about the analysis of factors related to the recovery of pulmonary TB patients showed that poor behavior can reduce the cure rate of $\mathrm{TB}$ patients. This was in line with Hariwijaya and Sutanto who mention that cases of healing or the success of TB treatment are determined by a behavioral factor. Some of the behaviors that can be done by pulmonary TB sufferers include eating nutritious foods, stop smoking, not spitting in any place, closing the mouth if coughing or sneezing and resting a lot especially in a well-ventilated place.

A study by Perez et al. (2012) state that alcohol use behavior has $51 \%$ greater risk for default treatment $(\mathrm{p}=0.001)$ compared to those who did not consume alcohol.

\section{The Effect of Smoking on TB Patients Recovery}

The result of analysis showed that there was a direct and negative influence of patients who smoke on the cure of tuberculosis patients and the effect was statistically significant $(b=-1.50$; CI 95\%= -2.56 to $0.43 ; \mathrm{p}=0.006)$. This study showed that $\mathrm{TB}$ patients who smoke can reduce the recovery of TB patients by 1.50 times higher than those who did not smoke.

Ndwandwe et al. (2018) show that TB patients who smoke have a risk to reduce TB disease recovery $(\mathrm{p}=0.020)$. Sayidah et al. (2018) explain that there was a significant effect of smoking on tuberculosis.

\section{AUTHOR CONTRIBUTION}

Tri Godha Fitriani, the main author who played a role in collecting and processing study data; Setyo Sri Rahardjo, examined the conceptual framework and author methodology; Hanung Prasetya, analyzed 
the data and interpreted the results of the analysis.

\section{FUNDING AND SPONSORSHIP}

This study used personal funds by the main authors.

\section{CONFLICT OF INTEREST}

The authors did not have any conflict of interests.

\section{ACKNOWLEDGEMENT}

We would like to thank to the Health Center for helping the process of this study and the respondents who have participated and were willing to become the respondents of this study.

\section{REFERENCE}

Alvaro-Meca A, Diaz A, de Miguel DJ, Resino R, Resino S (2016). Environmental factors related to pulmonary tuberculosis in HIV-infected patients in the Combined Antiretroviral Therapy (cART) Era. PLoS ONE, 11(11): e0165944. doi:10.1371/journal.pone.0165944

Djibuti M, Mirvelashvili E, Makharashvili $\mathrm{N}$, Magee MJ (2014). Household income and poor treatment outcome among patients with tuberculosis in Georgia : a cohort study, BMC Public Health. BMC Public Health, 14(1):18. doi: 10.1186/1471-2458-14-88.

Dinas Kesehatan 2018. Profil Kesehatan Kabupaten Bantul (Bantul Regency Health Profile). Retrieved from https://dinkes.bantulkab.go.id/data/ hal/1/8/23/57-profil-kesehatan-2018. Goldhaber-Fiebert JD, Jeon CY, Cohen T, Murray MB (2011). Diabetes mellitus and tuberculosis in countries with high tuberculosis burdens: Individual risks and social determinants, Inter- national Journal of Epidemiology, 40(2): 417-428. doi: 10.1093/ije/dyq238.

Hamidi S, Raharjo SS, Wijaya M (2019). Path Analysis on the Determinants of Adherence to Anti Tuberculosis Drug Treatment in Kaur District, Bengkulu, Indonesia. Journal of Epidemiology and Public Health, 4(3): 205-214. doi: 10.26911/je-public-health.2019.04.03.08.

Jalal TMT, Abdullah S, Wahab FA, Dir S, Naing NN (2017). Prevalence and factors associated with the tuberculosis treatment success among TB/HIV co-infection in North-East Malaysia. Clinical Infectious Diseases, 54(10): 1485-1494. doi: 10.21315/mjms2017.24.6.9.

Kemenkes RI (2014). Pedoman Nasional Pengendalian Tuberkulosis (National Tuberculosis Control Guidelines). Jakarta: Kementerian Kesehatab RI. Retrieved from http://www.dokternida.rekansejawat.com/dokumen/DEPKES-Pedoman-Nasional-Penanggulangan-TBC-2011-Dokternida.com.pdf

Kemenkes RI (2018). Profil Kesehatan Indonesia 2017 (Indonesian Health Profile 2017). Jakarta: Kementerian Kesehatan RI. Retrieved from: http:// www.pusdatin.kemkes.go.id/resources/download/pusdatin/profil-kesehatan-indonesia/Data-dan-Informasi_Profil-Kesehatan-Indonesia-2017.pdf

Khaliq A, Khan IH, Akhtar MW, Chaudhry $\mathrm{MN}$ (2015) Environmental risk factors and social determinants of pulmonary tuberculosis in Pakistan. Epidemiology (sunnyvale), 5(3): 201. doi:10.4172/2161-1165.1000201

Kholifah N (2009). Analisis faktor yang berhubungan dengan kesembuhan 
penderita TB paru (Analysis of factors related to the recovery of pulmonary TB patients). KEMAS Jurnal kesehatan masyarakat, 3(4). Retrieved from https://lib.unnes.ac.id/4007/1/560o.pdf.

Ndwandwe ZSI, Mahomed S, Lutge E, Knight SE (2018). Factors affecting nonadherence to tuberculosis treatment in Umgungundlovu Health District in 2010. Southern African Journal of Infectious Diseases, 29(2): 5659. doi: $10.1080 / 23120053.2014 .114-$ 41570.

Nizar M (2017). Pemberantasan dan penanggulangan Tuberkulosis (Eradication and prevention of tuberculosis). Pemberantasan Dan Penanggulangan Tuberkulosis. Yogyakarta: Gosyen Publishing.

Perez-porcuna M, Brito A, Garrido MDS, Penna ML, Marreiro LDS, Albuquerque BC, Martinez-Espinosa FE, et al (2012). Factors associated with tuberculosis treatment default in an endemic area of the Brazilian Amazon, a case. PLoS ONE, 7(6): e39134. doi: 10.1371/journal.pone.0039134.
Puspitasari, Mudigdo A, Adriani RB (2017). Effects of education, nutrition status, treatment compliance, family income, and family support, on the cure of Tuberculosis in Mojokerto, East Java. Journal of Epidemiology and Public Health, 02(02): 141-153. doi: 10.26911/jepublichealth.2017.02.02.05

Puspitasari L, Murti B, Demartoto A (2017). Social Support on the adherence to treatment of tuberculosis in Cilacap Indonesia. Journal of Epidemiology and Public Health, 01(01): 58-65. doi: 10.26911/jepublichealth.2016.01.01.07.

Sayidah D, Rahardjo SS, Murti B (2018). Risk factors of tuberculosis: A new path analysis evidence from Ponorogo, East Java. Journal of Epidemiology and Public Health, 3(3): 353-360 https://doi.org/10.26911/jepublichealth.2018.03.03.06

WHO (2017). TB report 2017 WHO. Geneva: World Health Organization

WHO (2018). Global Tuberkulosis Report 2017. Geneva: World Health Organization 